\title{
Effect of Mastitis Treatment and Somatic Cell Counts on Milk Yield in Danish Organic Dairy Cows
}

\author{
T. W. Bennedsgaard, ${ }^{\star}$ C. Enevoldsen,† S. M. Thamsborg, $\ddagger$ and M. Vaarst§ \\ *Department of Animal Husbandry and Animal Health and \\ †Department of Clinical Studies and \\ ‡Department of Veterinary Microbiology, The Royal Veterinary and Agricultural University, \\ 1870 Frederiksberg C, Denmark \\ §Danish Institute for Agricultural Science, P.O. Box 50, 8830 Tjele, Denmark
}

\begin{abstract}
Production and disease data from 17,488 lactations in 48 Danish organic dairy herds from 1997 to 2001 were analyzed to obtain estimates on the effect of somatic cell counts (SCC) and mastitis treatment on milk production. A multilevel three-parameter piecewise random coefficients linear model with energy-corrected milk (ECM) as dependent variable and herd, lactation, and test days as levels, was used to model the lactation curve. Covariates related to production, SCC, veterinary treatments, and reproductive performance in the previous lactation as well as information on other diseases in the current lactation were included to describe the production capacity of the individual cow. The average daily milk production at herd level was 20.8, 24.2, and $25.8 \mathrm{~kg}$ of ECM/d in first, second, and third or later lactation. The estimates for production losses were on average $0.2,0.3$, and $0.4 \mathrm{~kg}$ of ECM/d in first, second, and third or later lactation with each twofold increase in SCC between 100,000 and 1,500,000 cells $/ \mathrm{ml}$. The effect varied with the stage of lactation and was nonsignificant around $60 \mathrm{~d}$ postpartum and highest at the end of the lactation. The production losses in cows treated for mastitis varied with parity and stage of lactation and were modified by the SCC after treatment. For a cow in third lactation with a SCC below 100,000 cells/ $\mathrm{ml}$ before treatment at days in milk $=15$, the predicted loss was $435 \mathrm{~kg}$ of ECM, including a loss of $135 \mathrm{~kg}$ of ECM because of higher SCC compared with the level before treatment. Most of the variation in production related to SCC and mastitis was at the lactation level, and no significant differences were found between herds grouped according to milk production level, SCC, or prevalence of mastitis treatment.
\end{abstract}

Received October 25, 2002.

Accepted April 7, 2003.

Corresponding author: T. W. Bennedsgaard; e-mail: TorbenW. Bennedsgaard@agrci.dk.
(Key words: organic farming, herd health, milk production, effect of disease)

\section{Abbreviation key: ECM = energy-corrected milk. \\ INTRODUCTION}

Knowledge about estimates of production losses due to high SCC and treated cases of IMI is highly relevant for selection of appropriate disease control measures in dairy herds. The continuing development of statistical methods and programs for their application gives new possibilities to estimate trends more reliably. Reviews on previous analyses have been published recently and show considerable variation in the estimates (Hortet and Seegers, 1998a, 1998b). Most publications have dealt with either the effect of mastitis (i.e., treated cases) or the effect of elevated SCC without exploring a possible combined effect or effect modification. This is also the situation for the more recent papers. Koldeweij et al. (1999) estimated loss in production based on weekly recordings of production and SCC. They used a dataset corrected for year-season and production levellactation stage with correction factors calculated from the healthy cows in the dataset (SCC $<200,000$ and no mastitis treatment). Data were analyzed by a least squares analysis of variance, with the effect of breed and the random effect of animal within breed in the model. They found a linear correlation between $\log 10$ (SCC) and production for the whole range of SCC values. There was no correction for mastitis treatment in the model. Hortet et al. (1999) estimated the effect of milk yield on SCC and found that the effect varied with parity. The effect also varied with lactation stage for parity 2 and greater. Data from 150 herds were analyzed in a general mixed model. Records occurring after a mastitis treatment were excluded. Stage of lactation was modeled as 30 classes of DIM. A categorical variable for herd-season was included as random effect. A reference value for SCC was set at 50,000 cells $/ \mathrm{ml}$, and test days with SCC $>600,000$ were excluded due to large variation in the estimated relationship to milk 
production. No corrections were made for production capacity of the individual cow (e.g., by including production in previous lactation) or specific herd factors. Other studies have shown significant genetic correlation between production and health (Simianer et al., 1991; Heringstad et al., 2001). Preferential treatment including differences in days open, length of dry period, and criteria for mastitis treatment might also affect the estimates without correction (Kuhn et al., 1999).

Østergaard and Gröhn (1999) estimated the loss of production in energy-corrected milk (ECM) using a disease index for the time before or after treatment or the occurrence of other diseases on weekly production data from three research farms. Several diseases were separately evaluated using models of the lactation curve with linear, quadratic, and cubic continuous covariates for lactation stage in a repeated measures analysis with first-order autoregressive covariance structure. Breed, parity, and calving season were included in the models. The model contained random effects for each treatment group within trials. For mastitis they found a higher milk yield for multiparous cows 2 to 4 wk before treatment and for all parities a negative effect on milk yield from $1 \mathrm{wk}$ before disease and the rest of the lactation. No correction was made for SCC or production in previous lactation. Rajala-Schultz et al. (1999) estimated the loss of milk yield after treated cases of mastitis using a mixed model with monthly test milk yield as the outcome variable and a first-order autoregressive correlation structure. Their analysis was based on data from 24,276 cows that were followed for a single lactation. Milk yield was evaluated in relation to two different baselines: production of healthy cows and production before clinical diagnosis and treatment. When compared with the cows own production, the analysis was related to three stages of lactation: before peak yield of the individual cow, from peak to $120 \mathrm{~d}$ postpartum and from $120 \mathrm{~d}$ postpartum to calving. In these models, a mastitis index was used to categorize test days in relation to the time period before or after mastitis treatment. Season, stage of lactation, and disease variables were included as fixed effects. Random effects at herd level were only included in the model for a subset of data because of the need for computer power. Cows treated for mastitis were found to have higher yields both before and after treatment compared with cows not treated for mastitis. When compared to the cows' own production, a negative effect on production could be seen up to 4 wk before treatment.

The herds in the present study were all certified organic herds for the whole study period. In some studies (Vaarst et al., 1993; Hardeng and Edge, 2001), organic herds have been shown to have fewer veterinary treatments for mastitis. This might be a result of better udder health, but it could also be a result of the organic farmers being more reluctant to use antibiotics, which might eventually lead to chronic infections or treatment at a later time in relation to the initial infection. The regulations for Danish organic production allow only veterinarians to treat cattle older than 6 mo. The absence of treatments by the farmers is expected to result in more reliable registration of mastitis treatments because the treatment will be registered both in the herd and by automatic electronic reporting to the Danish Cattle database.

The aim of this study was to estimate the combined effect of the SCC and treatment for mastitis on milk production in a model allowing for correction for other factors affecting production, including information on the previous lactation, and to explore possible interactions between the parameters. New software and the general availability of more powerful computers allow for more complex models that account for herd- and cow-specific factors and analysis of the variance components by using multilevel modeling with random effects on herd and lactation level. To take into account the eventual change in the shape of the lactation curve due to health status and herd-specific factors, Singer (1998) chose a random coefficients linear model. This approach gives the possibility of making inferences on the effect on herd and cow level.

\section{MATERIALS AND METHODS}

\section{Data Collection}

Data were available from 48 organic herds. The herds were randomly chosen by inviting every second organic farmer in the southern part of Denmark with at least 2 yr of organic production in 1999. Forty-eight out of 105 invited farmers accepted the invitation. Eighteen of the herds participated in the development of a herd health program for organic dairy herds from 1999 to 2001, and 19 of the herds served as controls in the project. Eleven herds participated in another project regarding use of veterinary treatments. Monthly registration of daily milk production, SCC, diagnoses, and dates of veterinary treatments, dates of reproductive events, and culling were available at cow level from the Danish Cattle Database. Records for every single treatment were registered in the Danish Cattle Database. Data on disease treatments were crosschecked using the mandatory milk and meat withdrawal notes of the veterinarian.

Records from cows calving between January 1, 1997, and March 1, 2001, were included in the analysis. Test days before $9 \mathrm{~d}$ postpartum were excluded because of the natural high SCC at the start of lactation. Records after d 305 were excluded because of few observations 
and possible effects of preferential treatment due to drying off or culling (Enevoldsen et al., 2000).

Test-day records $(\mathrm{n}=128,153)$ were available. Records with missing information $(n=1858)$ on age at first calving, gestation length, days open antepartum, or milk production in previous lactation were excluded.

The last test day was excluded for cows culled between $\mathrm{d} 210$ and 320 postpartum because these observations tended to show a sudden drop in milk production. The resulting dataset consisted of 118,427 records from 17,488 lactations of 9317 cows. Seventy-four percent of the cows were Danish Holstein-Fresian, 16\% Jersey, and the last $10 \%$ primarily cross-breed cows.

\section{Statistical Analysis}

Because of the differences in the shape of the lactation curve and the inclusion of information on the previous lactation, the data were analyzed separately for parities 1, 2, and 3 or higher. Continuous variables were centered about the grand mean for each lactation to make interpretation of the results easier and decrease numerical problems associated with inclusion of polynomials (Kreft et al., 1995).

Only a limited number of observations are available from each lactation with monthly registrations. To use this information, including observations from lactations with few or missing test days, a very simple multilevel three-parameter piecewise linear random coefficients linear model was used to analyze the data. The MLwiN 1.1 (Institute of Education, London) was used for the analyses (Rasbash et al., 2001). The three levels in the model were herd, lactation, and test day. The monthly milk yields as ECM were used as the outcome variable (Sjaunja et al., 1990).

The shape of the lactation curve was modeled as a two-piece linear function of DIM. For DIM $\leq 60$ two variables, DIMun60 and DIM60 were calculated as DIMun60 = (DIM-60)/60 and DIM60 = 0; for $60 \leq$ DIM $\leq$ 305 , the two variables were calculated as DIM60 = $(\mathrm{DIM}-60) / 245$ and DIMun60 $=0$. The model gives a lactation curve that "peaks" at d 60 postpartum. The baseline model is

$$
\begin{gathered}
\mathrm{ECM}_{\mathrm{ijk}}=\beta_{0}+v_{0 \mathrm{k}}+\mathrm{u}_{0 \mathrm{jk}}+\beta_{1} \mathrm{DIMun}_{\mathrm{ijk}} \\
+v_{1 \mathrm{k}} \mathrm{DIMun} 60_{\mathrm{ijk}}+\mathrm{u}_{1 \mathrm{jk}} \mathrm{DIMun}_{\mathrm{ijk}}+\beta_{2} \mathrm{DIM}_{\mathrm{ijk}} \\
+v_{2 \mathrm{k}} \mathrm{DIM} 0_{\mathrm{ijk}}+\mathrm{u}_{2 \mathrm{jk}} \mathrm{DIM} 0_{\mathrm{ijk}}+\varepsilon_{0 \mathrm{ijk}}
\end{gathered}
$$

where

$\mathrm{ECM}_{\mathrm{ijk}}$ represents $\mathrm{ECM}$ in $\mathrm{kg} / \mathrm{d}$ on test day $\mathrm{i}$ of the jth lactation in the kth herd;

$\beta_{0}$ represents the expected milk yield at $d 60$ postpartum (DIM60 = 0 and DIMun60 =0); $v_{0 \mathrm{k}}$ represents departure of the kth herd from the overall mean;

$\mathrm{u}_{0 \mathrm{jk}}$ represents the departure of the jth lactation from the overall mean in the kth herd;

$\beta_{1}$ DIMun60 $0_{\mathrm{ijk}}$ and $\beta_{2} \mathrm{DIM}_{\mathrm{ijk}}$ represent the overall mean slope before and after d 60 postpartum;

$v_{1 \mathrm{k}} \mathrm{DIMun} 60_{\mathrm{ijk}}$ and $v_{2 \mathrm{k}} \mathrm{DIM} 60_{\mathrm{ijk}}$ represent the departure of the kth herd from the overall mean slope before and after d 60 postpartum;

$\mu_{1 \mathrm{jk}} \mathrm{DIMun} 60_{\mathrm{ijk}}$ and $\mu_{2 \mathrm{jk}} \mathrm{DIM} 60_{\mathrm{ijk}}$ represent the departure of the jth lactation in the kth herd from the overall mean slope before and after d 60 postpartum;

$\varepsilon_{0 \mathrm{ijk}}$ represents the residual variance; and the random variables $v_{0 \mathrm{k}}, \mu_{0 \mathrm{jk}}, v_{1 \mathrm{k}}$ DIMun60 $0_{\mathrm{ijk}}, \mu_{1 \mathrm{jk}} \mathrm{DIMun} 60_{\mathrm{ijk}}, v_{2 \mathrm{k}}$ DIM60 $0_{\mathrm{ijk}}, \mu_{2 \mathrm{jk}} \mathrm{DIM} 60_{\mathrm{ijk}}$, and $\varepsilon_{0 \mathrm{ijk}}$ are assumed normally distributed with zero mean. The variances for the random parameters were estimated. Random parameters within the same level were analyzed as correlated and covariances were estimated.

This model provides estimates of completely individual lactation curves for each lactation. Dependency between lactations from the same cow is accounted for by inclusion of variables on production in the previous lactation. The reason for rescaling the stages of lactation (DIMun60 and DIM60) was to allow for a more straightforward interpretation of the random effects as suggested by Singer (1998).

Effects of fixed and random variables on lactation and test-day level were tested in the model. Variables included information on days open, length of gestation and dry period, milk production, SCC and veterinary treatments in the previous lactation and in the dry period, as well as information on calving complications, SCC, and veterinary treatments in actual lactation. Polynomials and interactions between all variables were tested. Development over time and seasonal changes were modeled by a centered continuous variable for the time and linear, quadratic, and cubic terms for the calving month. The log-likelihood given by the iterative generalized least squares estimation of MLwiN 1.1 was used to include or exclude the variables by performing $\chi^{2}$-tests with a $5 \%$ alpha significance level. Excluded variables were reintroduced and tested in the final model (Goldstein, 1995).

A basic unstructured covariance structure was used.

The SCC were divided by 1000 and converted to the natural logarithm (LNSCC) to account for the skewness to the right of SCC distribution (Ali and Shook, 1980). SCC below 100,000 cells/ml was used as reference and set to zero because only a weak nonsignificant relation between SCC and production as $\mathrm{kg}$ ECM was seen throughout the lactation for SCC between SCC 0 and 100,000. The effect of the SCC was modeled by two variables. The first variable had the value $\ln (\mathrm{SCC})-$ 
$\ln (100)$ for SCC from 100,000 to $1,500,000$ cells $/ \mathrm{ml}$ and the value $\ln (1500)-\ln (100)$ for SCC above $1,500,000$ cells $/ \mathrm{ml}$. The other variable had the value $\ln (\mathrm{SCC})$ $\ln (1500)$ for SCC above $1,500,000$ cells $/ \mathrm{ml}$ and was zero for SCC below 1,500,000 cells $/ \mathrm{ml}$. Interactions with DIM60 and DIMUN60 were tested, but only the interactions with DIM60 were retained in the models. These variables all showed a linear relationship to ECM.

Hortet et al. (1999) showed that an interaction between LNSCC and DIM and DIM*DIM gave a better fit when modeling SCC and milk yield. In their analysis they excluded test days $<15$ because they showed a stronger effect of SCC on milk yield only for second parity. In our dataset, the same effect was seen for DIM $<16$ in second and later lactations. Because an exploration of the data did not show any signs of this effect being a result of outliers or problems with the basic model the relationship was modeled by adding an extra variable for SCC for $\mathrm{DIM}<16$ together with a dummy variable for $\mathrm{DIM}<16$. These variables gave a good fit to the data. The deviation from the general trend might be a result of cows with a prolonged production of colostrum having lower production.

Mastitis treatment was modeled by a series of variables for treatment 0 to $14 \mathrm{~d}$ before calving, from calving to $\mathrm{d} 60$ and from d 60 to 305 . The variables take the value of 1 from the first test day after treatment. Separate variables for the second treatment in the lactation were also introduced. For the few cases of a third or fourth mastitis treatment two variables taking the value of 1 on the first test day after treatment only were introduced.

Interaction terms with the number of days after treatment and DIM were tested, and one of them was included for most variables related to treatment. Random effects were included in the models for SCC and mastitis treatment. Interaction terms between the variables for SCC and the variables for mastitis treatment were tested and found nonsignificant. To test this result, the model was run after exclusion of all cows treated for mastitis. The estimates for the effect of SCC on milk production were similar to the estimates with the full dataset.

The distribution of the residuals was tested for normality by graphical exploration in MLwiN.

The predictions from the model were analyzed for preferential culling of cows in relation to SCC and mastitis treatment by linear regression with predicted loss in $\mathrm{kg} / \mathrm{ECM}$ per day as outcome and DIM at culling as explanatory variable. Cows not culled at d 305 after treatment were excluded from the analysis.

\section{RESULTS}

Results of descriptive data analysis at herd level for parities 1, 2, and 3+ are given in Table 1. The herd size varied from 20 to 198 cows, and the mean herd size was 85 cows in 1997 and 98 cows in 2001. The median DIM for first mastitis treatment was 32,38 , and 34 in first, second, and later lactations, respectively. The variables of the final models are given in Table 2.

\section{Test-Day Production Loss}

The effects of both mastitis treatment and SCC varied with parity and stage of lactation. The predicted loss of milk production for selected cell counts and stages of lactation are shown in Table 3. In all parities, the negative effect of SCC below 1,500,000 cells $/ \mathrm{ml}$ was lowest around d 60 and highest at the end of lactation, resulting in a steeper decline of the lactation curve (poor persistency). For higher cell counts, the effect varied less with stage of lactation. Figure 1 shows the relation between SCC, DIM, and loss of milk production in parity 1. Cows treated once for mastitis had lower production in all herd groups except for mastitis treatments of heifers in the first $14 \mathrm{~d}$ of lactation. For the heifers a small nonsignificant positive effect with a very large standard error was found for mastitis treatment in the first $14 \mathrm{~d}$ of lactation, and the variable was excluded from the model. In parities 2 and $\geq 3$, the negative effect of mastitis treatment was significantly reduced with time after treatment for treatments before $d 15$ for parity 2 and for treatments before d 60 for parities $\geq 3$. Predictions for loss of milk production for first mastitis treatment at DIM $-7,15,50$, and 150 are shown in Table 3. Estimates of the effect of a second mastitis treatment during the lactation was only found significant in second and higher lactation and was smaller than the effect of the first treatment $(-0.9 \mathrm{~kg}$ of ECM/ $\mathrm{d}$ for treatments at d 16 to $60 ;-0.2 \mathrm{~kg}$ of ECM/d for treatments after d 60 in parity 2 and $-0.8 \mathrm{~kg}$ of ECM/ $\mathrm{d}$ for treatments after $\mathrm{d} 60$ in parity $\geq 3$ ). The inclusion of a variable for third and fourth treatments showed a very large standard error and resulted, in general, in nonsignificant positive estimates. Udder treatments with antibiotics at drying off were given to 15 and $20 \%$ of the cows that were not culled in first and later lactations. Udder treatment at drying off did not result in a significant change in milk production in the following lactation.

Cows treated for mastitis in the previous lactation had higher production than cows not treated in the previous lactation. For cows in third lactation or later, the estimates were 0.3 and $0.7 \mathrm{~kg}$ of ECM/d for cows treated one or at least two times, respectively. The geometric SCC of the last three test days at the end of the previous lactation also affected the production in the next lactation for cows in third lactation or older. The estimate was $0.2 \mathrm{~kg}$ of ECM/d higher production per 
Table 1. Parity specific distribution of herd level averages of milk production, SCC, and incidences of mastitis and other disease treatments. ${ }^{1}$

\begin{tabular}{|c|c|c|c|c|c|c|c|c|c|c|c|c|}
\hline & \multicolumn{4}{|c|}{$\begin{array}{l}\text { Parity } 1 \\
(\mathrm{n}=48)\end{array}$} & \multicolumn{4}{|c|}{$\begin{array}{l}\text { Parity } 2 \\
(\mathrm{n}=48)\end{array}$} & \multicolumn{4}{|c|}{$\begin{array}{c}\text { Parity } 3+ \\
(\mathrm{n}=48)\end{array}$} \\
\hline & Mean & Q1 & Q2 & Q3 & Mean & Q1 & Q2 & Q3 & Mean & Q1 & Q2 & Q3 \\
\hline Energy-corrected milk (kg/day) & 20.8 & 19.3 & 20.5 & 22 & 24.2 & 22.3 & 24.2 & 25.8 & 25.8 & 23.5 & 25.5 & 27.2 \\
\hline SCC $(\times 1000$ cells/ml $)$ & 190 & 162 & 194 & 233 & 139 & 105 & 147 & 180 & 204 & 217 & 204 & 172 \\
\hline $\begin{array}{l}\text { Mastitis treatments } \\
\text { (\% since last test day) }\end{array}$ & 2.6 & 1.4 & 2.0 & 3.4 & 4.2 & 2.6 & 3.5 & 5.2 & 5.0 & 2.7 & 4.8 & 6.3 \\
\hline (\% treated during lactation) & 9.7 & 5.3 & 8.6 & 13 & 10 & 5.8 & 9.5 & 12.6 & 20.9 & 14.6 & 20.5 & 27.2 \\
\hline
\end{tabular}

${ }^{1} \mathrm{Q} 1, \mathrm{Q} 2, \mathrm{Q} 3$ = quartiles.

unit increase in the average of $\ln (\mathrm{SCC})$ for the last three test days before drying off.

\section{Combined Effect of SCC and Mastitis Treatment}

Treatment for mastitis was, in general, followed by a change in SCC. The analysis showed that cows with low SCC at the last test day before mastitis treatment in general had higher SCC after treatment, whereas cows with high cell counts before treatment $(>700,000$ cell $\mathrm{s} / \mathrm{ml}$ ) on average showed a decline in SCC after treatment. To obtain the final estimate for changes in milk production the treatment effect should be combined with the effect of the change in SCC. The resulting lactation curves for cows in parities 1 and 3 with three different levels of SCC before treatment at DIM $=50$ and 150 are shown in Figures 2 and 3 . The mean of the two previous test days was used to calculate the SCC before treatment.

In first lactation a cow treated for mastitis at DIM $=50$ and with a SCC below 100,000 cell $/ \mathrm{ml}$ before treatment had a predicted loss in total production of $250 \mathrm{~kg}$ of ECM, including a loss of $45 \mathrm{~kg}$ because of a higher SCC compared with the level before treatment. For treatment at DIM $=150$ in first lactation the predicted loss from d 150 to 305 postpartum was $32 \mathrm{~kg}$ of ECM for cows with a SCC below 100,000 before treatment and $78.5 \mathrm{~kg}$ of ECM for cows with a SCC above $2,000,000$ cells $/ \mathrm{ml}$ before treatment. For a cow in third lactation treated for mastitis $15 \mathrm{~d}$ postpartum with a SCC below 100,000 cells/ml before treatment, the predicted loss was $435 \mathrm{~kg}$ of ECM including a loss of 135 $\mathrm{kg}$ of ECM because of a higher SCC compared with the level before treatment. A cow in third lactation treated $15 \mathrm{~d}$ postpartum with a SCC above $2,000,000$ cells $/ \mathrm{ml}$ before treatment and an average development in SCC after treatment had a loss of $600 \mathrm{~kg}$ ECM compared with a cow with low SCC and no mastitis treatment. However, the predicted production would still be 270 $\mathrm{kg}$ of ECM higher than a cow with a constant SCC at $2,000,000$ and no mastitis treatment.

\section{Effect of Herd}

No significant differences between groups of herds with low or high calculated bulk tank SCC, low or high prevalence of mastitis treatment, low or high milk production per cow, or combinations of these groupings could be found. The variance of the effect of mastitis treatment and SCC between animals was much larger than between herds, and no random effects related to SCC or mastitis treatment were significant on herd level when random effects on lactation level were included in the model. The inclusion of variables for SCC and mastitis treatment without random effects explained 4,5 , and $2 \%$ of the variation at DIM $=60$ at test day, lactation, and herd level, respectively.

\section{Culling and Production Loss}

Cows treated for mastitis before DIM $=60$ were culled earlier than other cows. A total of $17 \%$ of the cows in parity 3 or higher were culled before DIM $=200$. Twenty-six and forty percent of the cows were culled before $\mathrm{d} 200$ postpartum for the cows treated for mastitis before DIM = 15 with a SCC between 750,000 and $2,000,000$ cells $/ \mathrm{ml}$ or above $2,000,000$ cells $/ \mathrm{ml}$ before treatment (significant difference, $P<0.05$ ). Analysis of the estimated loss of production for these cows including both fixed and random effects on lactation level for SCC and mastitis treatment showed that the cows culled early in the lactation have larger estimated loss of production ( $\mathrm{kg}$ of $\mathrm{ECM} / \mathrm{d}$ ) due to mastitis and SCC (Figure 4).

\section{DISCUSSION}

\section{Lactation Curves}

The predicted lactation curves for kilogram of ECM had a negative slope from DIM $=9$ to 60 , and this was very similar to the slope from DIM $=60$ to DIM $=305$. Such a shape is sometimes called an atypical lactation curve (Gengler, 1996). The use of ECM instead of total 
Table 2. Fixed and random variables added to the baseline model in the three models for first, second and third or later lactations. ${ }^{1}$

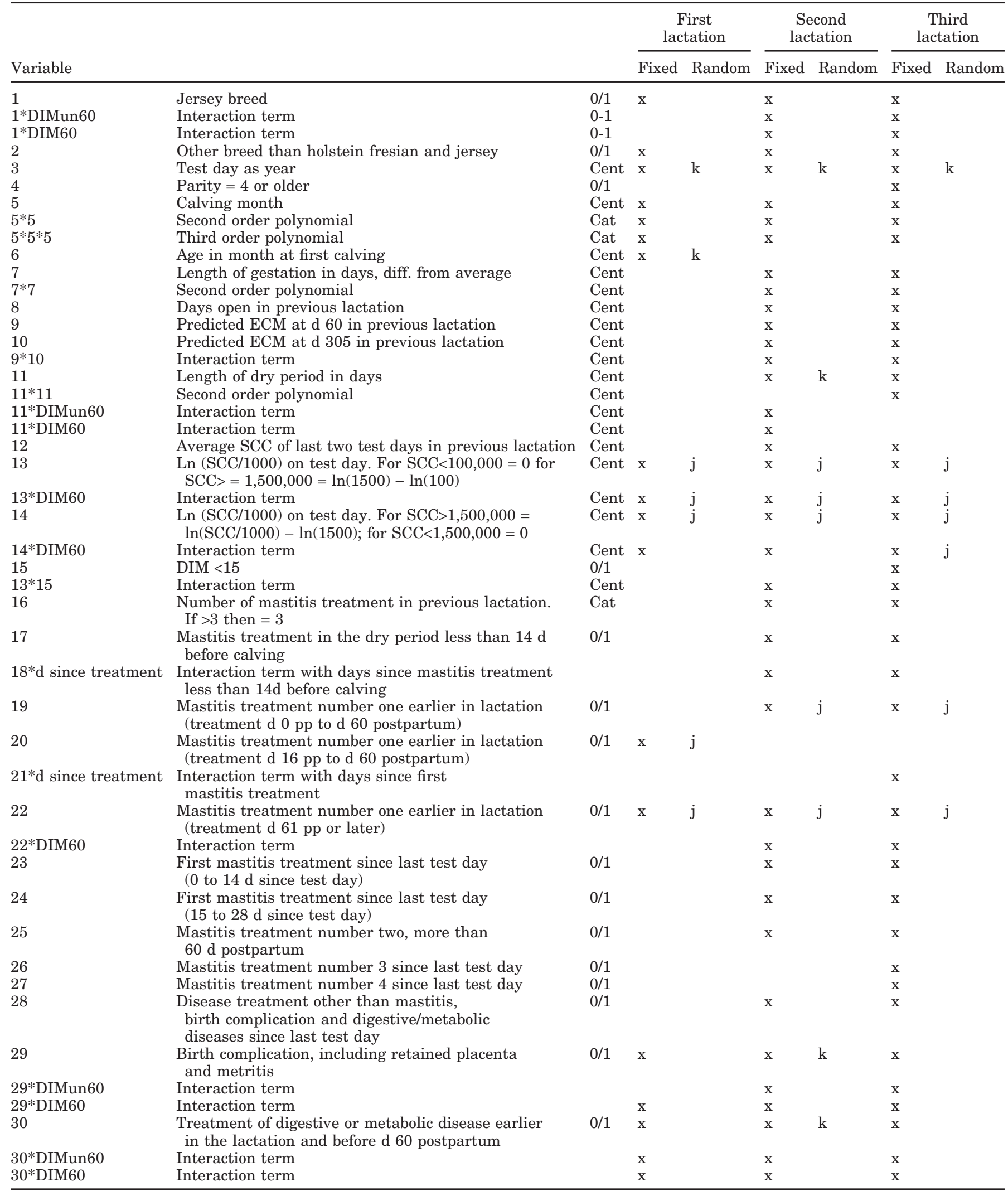

${ }^{1}$ Cent: Centered continuous variable; j: Random at lactation level; and k: Random at herd level. 
Table 3. Predicted loss of milk production ( $\mathrm{kg}$ of ECM/d) due to SCC or mastitis treatment at different stages of lactation for first/second/third or later lactations, respectively.

\begin{tabular}{lllll}
\hline & 15 DIM & 60 DIM & 150 DIM & 300 DIM \\
\hline SCC 200,000 cells/ml & $0.0 / 0.3 / 0.6$ & $0.0 / 0.0 / 0.2$ & $0.1 / 0.0 .3 / 0.4$ & $0.4 / 0.8 / 0.6$ \\
SCC 600,000 cells/ml & $0.0 / 0.8 / 1.4$ & $0.0 / 0.1 / 0.5$ & $0.3 / 0.8 / 0.9$ & $1.0 / 2.1 / 1.6$ \\
SCC 2,000,000 cells/ml & $0.3 / 1.4 / 2.3$ & $0.3 / 0.6 / 1.4$ & $0.8 / 1.5 / 1.6$ & $1.6 / 3.1 / 2.0$ \\
Mastitis d 7 before calving & NA/3.5/3.8 & NA/2.9/3.4 & NA/1.9/2.7 & NA/0.1/1.9 \\
Mastitis DIM 15 & $0 * / 1.6 / 2.2$ & $0 * / 0.9 / 1.0$ & $0 * / 0.9 / 0.9$ & $0 * / 0.9 / 0.8$ \\
Mastitis DIM 50 & NA & $0.8 / 0.9 / 1.1$ & $0.8 / 0.9 / 1.0$ & $0.8 / 0.9 / 0.8$ \\
Mastitis DIM 150 & NA & NA & $0.1 / 0.9 / 0.7$ & $0.1 / 0.9 / 0.1$ \\
\hline
\end{tabular}

*Nonsignificant estimate.

kilograms of milk produced as the response variable explains some part of this phenomenon. However, such a shape is a normal finding in organic herds in Denmark. The cows in organic herds are fed large amounts of roughage, often in a mixed ration with relative small amounts of concentrate compared with conventional herds. This type of feeding results in a lactation curve without any distinct peak and with a relatively good persistency (Kristensen and Kristensen, 1998; Bennedsgaard et al., 2003).

\section{Evaluation of Model}

When estimating the effect of mastitis on milk production only few, if any, test days from the recent lactation before treatment will be available as baseline for the estimation. In this study, this problem was handled by including information on production from the previous lactation as an estimate of cow production capacity. However, in first lactation, no information about previous production was available. The positive nonsignificant estimate obtained for mastitis treatment before $\mathrm{DIM}=15$ might be an estimation problem caused by

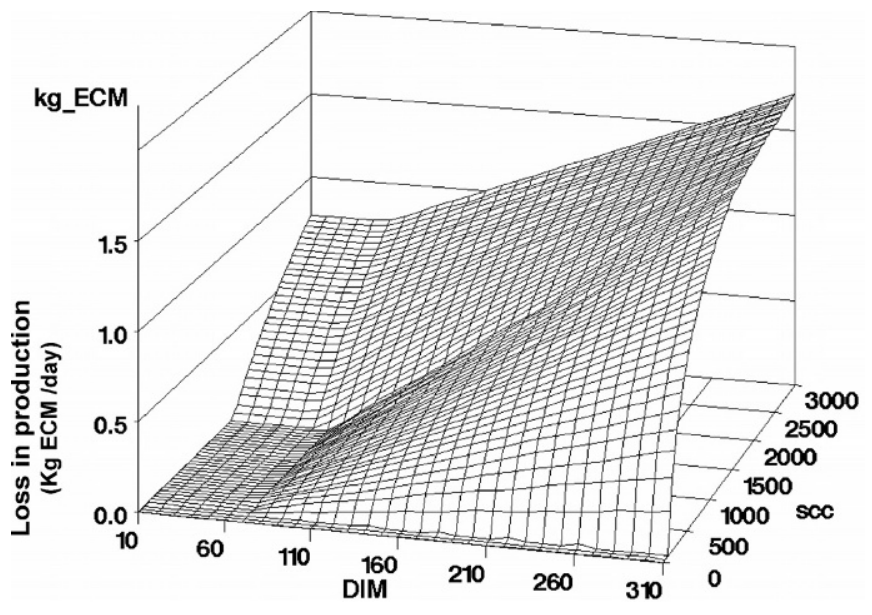

Figure 1. Effect of SCC on milk production as energy-corrected milk $(\mathrm{kg} / \mathrm{d})$ for SCC up to $3,000,000$ cells $/ \mathrm{ml}$ for cows in parity 1 . the lack of information about the production capacity of the cow. Inclusion of information on the genetic level of the heifers might change the estimate, but this was not available. The autoregressive models used in several studies (Østergaard and Gröhn, 1999; RajalaSchultz et al., 1999) allows the use of information from the previous test days for the same cow but might not be able to take account for an eventual prolonged decrease in milk production caused by a chronic infection before treatment. The multilevel model combined with the estimation of both the effect of SCC and mastitis treatment and other diseases allows a separation of the effect of udder infections into the subclinical effect of increased SCC and the effect of udder infections, which the farmers decides to treat. The multilevel models take into account the general characteristics of the lactation curves on the herd level and fits individual lactation

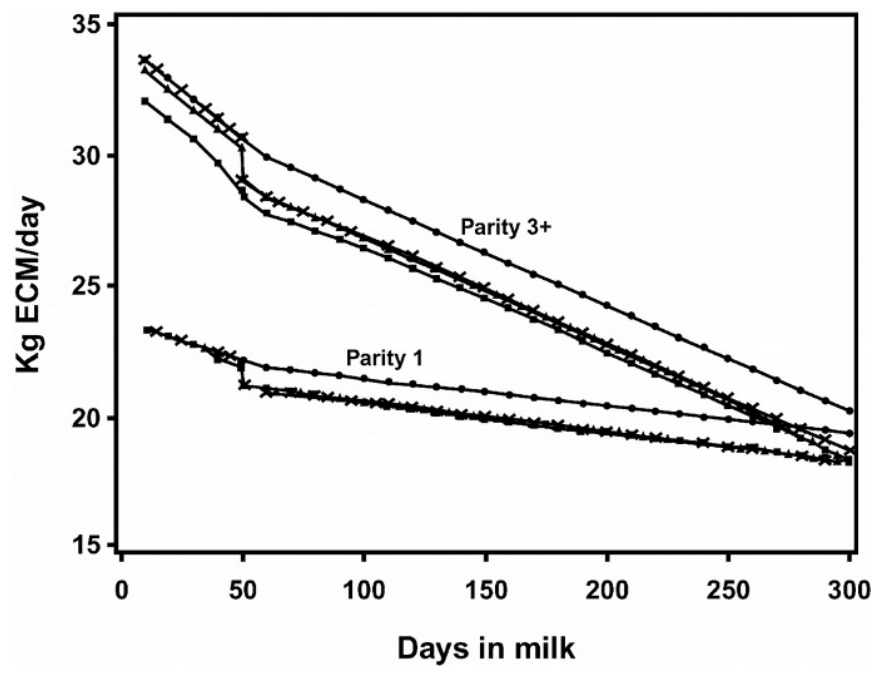

Figure 2. Predicted lactation curves for cows in parity 1 (lower curves) and parity 3 (upper curves) treated for mastitis at DIM 50 and average development of SCC after treatment. A SCC below 100,000 cells $/ \mathrm{ml}$ and no mastitis $(\mathbf{)})$ SCC below 100,000 cells $/ \mathrm{ml}$ before mastitis treatment, and mastitis at DIM 50 (X), SCC 350,000 cells/ml before mastitis treatment at DIM $50(\mathbf{\Delta})$ and SCC above 750,000 cells/ml before mastitis treatment at DIM $50(\mathbf{\square})$. 


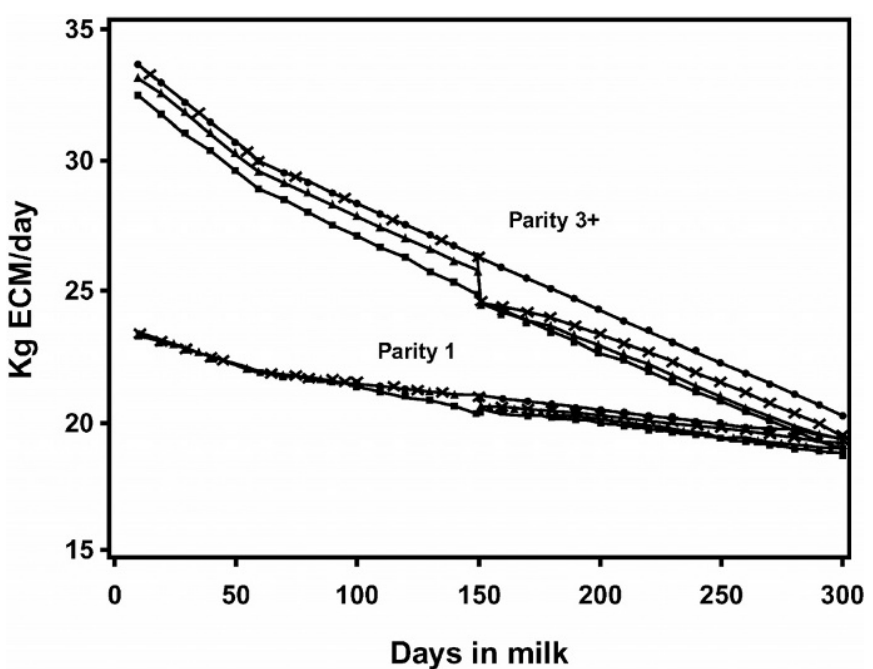

Figure 3. Predicted lactation curves for cows in parity 1 (lower curves) and parity 3 (upper curves) treated for mastitis at DIM 150 and average development of SCC after treatment. A SCC below $100,000 \mathrm{cells} / \mathrm{ml}$ and no mastitis $(\bullet)$, SCC below $100,000 \mathrm{cells} / \mathrm{ml}$ before mastitis treatment and mastitis at DIM 150 (X), SCC 350,000 cells $/ \mathrm{ml}$ before mastitis treatment at DIM $150(\mathbf{\Delta})$, and SCC above 750,000 cells $/ \mathrm{ml}$ before mastitis treatment at DIM 150 (ם).

curves for each cow. The inclusion of random effects for all variables for SCC and most variables for the first mastitis treatment gives the possibility of studying the variation in the responses to treatment. The effect of early culling of cows treated for mastitis is also controlled by using a multilevel model because the esti-

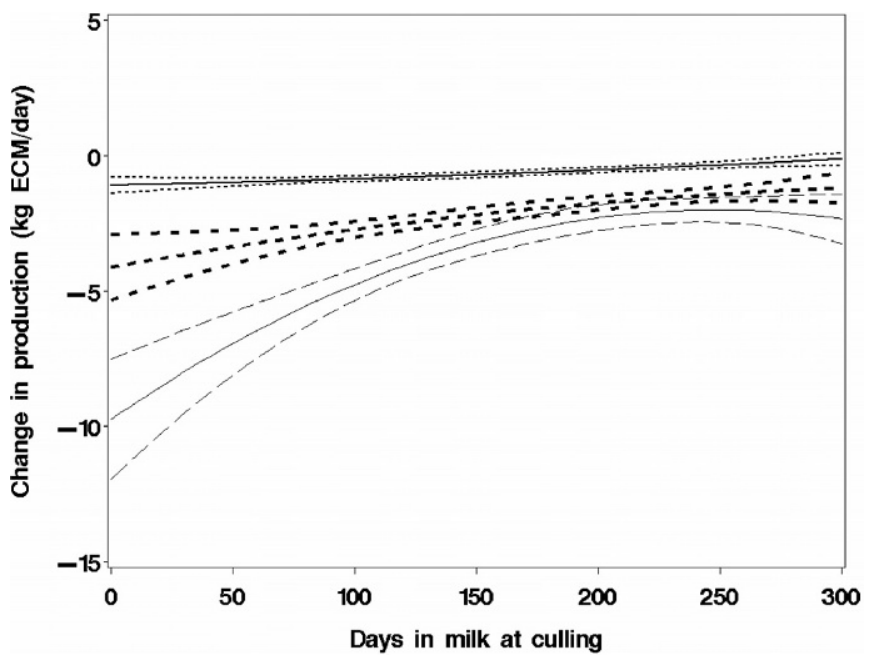

Figure 4. Mastitis treatment before d 60 postpartum. Estimated loss of production due to mastitis and SCC in relation to time of culling. No mastitis (thick line), SCC count below 750,000 before mastitis treatment (broken line), SCC count above 750,000 cells $/ \mathrm{ml}$ before mastitis treatment (thin line). Broken lines show 95\% confidence interval for the mean. mates are calculated based on the development in production on herd and cow level. However, no prediction for the SCC exists for the culled cows. Therefore, the development in the combined effect of mastitis treatment and SCC will be biased towards a lower estimate of the losses in late lactation compared with a situation in which no cows were culled. The very small change in production following mastitis treatment for cows with high SCC might be a result of these mastitis cases being of chronic character with little systemic effect on the cow, or it might be cows with no clinical signs treated with antibiotics to control the SCC. The relation between early culling and production loss of these cows further reduces the difference in the long-term losses in the predicted lactation curves.

The grafting point for the diphasic model for the relation between SCC and production was set at 1,500,000. This is high in comparison with other studies. Dentine and Daniel (1993) found a greater slope above 837,000 cells/ml. Hortet et al (1999) used 600,000 cells $/ \mathrm{ml}$ as exclusion criteria because of few observations above this level, and a higher variability in the response. The grafting point in this study was chosen after exploration of the residuals. The relationship between SCC and production was not fully linear, but the character of the relationship changed with stage of lactation with a lower grafting point in early lactation compared with the late lactation. This is in accordance with Jones et al. (1990). The effect of the SCC late in lactation decreased for SCC above 1,500,000 cells $/ \mathrm{ml}$. This is probably an estimation problem due to very few observations with high cell counts late in the lactation, and the estimate should be interpreted carefully.

\section{Effect of SCC}

Comparison of the effect of SCC on production between different studies can be difficult because of different outcomes and reference values. Hortet et al. (1999) used kilograms of milk as outcome, SCC below 50,000 cells $/ \mathrm{ml}$ as reference group, and excluded records with cell counts above 600,000 cell $/ \mathrm{ml}$ or following mastitis treatment. When running the same analysis on the dataset of this study for cows in parity 1 , the estimates obtained are identical to the results of the French study within $0.01 \mathrm{~kg}$ of milk at a given SCC. For higher parities, the average estimate over the lactation was also nearly identical though the change in the effect over the lactation was smaller in this dataset leading to lower predicted losses at the end of the lactation. Changing the outcome from ECM to noncorrected milk changes the change in the effect of SCC with lactation stage from being substantial to being nonsignificant $(0$ $\mathrm{kg}$ of $\mathrm{ECM} / \mathrm{d}$ at DIM $=60$ to $-0.8 \mathrm{~kg}$ of $\mathrm{ECM} / \mathrm{d}$ at DIM 
$=305$ for one unit change in $\ln (\mathrm{SCC})$ vs. $0.43 \mathrm{~kg}$ of milk/ $\mathrm{d}$ at DIM $=60$ to $0.40 \mathrm{~kg}$ of milk/d at DIM $=305$ for one unit change in $\ln (\mathrm{SCC})$ ). This difference is probably an effect of the SCC affecting the composition of the milk somewhat depending on the stage of lactation. The exclusion of records with SCC above 600,000 cells $/ \mathrm{ml}$ or following mastitis treatment did not change the estimates of the model in this study significantly indicating a robust estimation of the different parameters in the model. Koldeweij et al. (1999) estimated the effect of mastitis by using the SCC as the explanatory variable. The production loss was estimated to 0.5 and $1.0 \mathrm{~kg}$ of ECM/d per unit $\ln (\mathrm{SCC})$ for primiparous and multiparous cows compared with 0.3 and $0.6 \mathrm{~kg}$ of ECM/d for SCC below 1,500,000 in the present study. The estimates also included the effect of mastitis, and no grafting point was used to allow for a steeper slope at higher SCC. The estimates in the present study are in accordance with the conclusions of the most recent review, which summarized the results of previous papers. The conclusion of this review was a loss of $0.4 \mathrm{~kg}$ of milk/d in primiparous cows and $0.6 \mathrm{~kg}$ of milk/d in multiparous cows per twofold increase in SCC above 50,000 cells/ $\mathrm{ml}$ (Hortet and Seegers, 1998a). The fact that the estimates for the SCC variables did not change when excluding all records following mastitis treatment indicates that the effect of SCC and mastitis treatment should be modeled separately, though the combined effect of mastitis treatment and change in SCC should be calculated to get a reliable estimate.

\section{Effect of Mastitis Treatment}

In the most recent review of the effect of mastitis on milk yield, the total losses were summarized as 450 to $550 \mathrm{~kg}$ for treatments before peak, 200 to $300 \mathrm{~kg}$ on average for all the cases in first lactation, and 300 to $400 \mathrm{~kg}$ for later lactations with high variability (Hortet and Seegers, 1998b). A later study found rather similar estimates for first lactation, but higher estimates for parity 3+ with losses of 500 to $600 \mathrm{~kg}$ for treatment before peak and 300 to $400 \mathrm{~kg}$ after peak (RajalaSchultz et al., 1999). These estimates are comparable to the estimates in this study for older cows, whereas the predicted loss for first-lactation cows were substantially lower in our study. For the farmer, the milk loss will be substantially larger because in Danish organic herds, the withdrawal time after antibiotic treatment is 9 to $12 \mathrm{~d}$ after last treatment for a typical mastitis case. This will result in the withdrawal of about 350 $\mathrm{kg}$ of milk for a third-lactation cow at peak production.

It is important to beware of the broad definition of mastitis used in this and other studies. Mastitis treatment depends primarily on the farmer's selection of cows for treatment. This is also the case in this study, in which a veterinarian treated all cows. Cows treated might have had an IMI for a long period before veterinary treatment. The decision to treat the cows might be a result of clinical symptoms, an increase in SCC, a drop in milk production, or general problems in the herd with high bulk tank SCC leading to treatment of cows with high SCC. In contrast, the SCC of all milkproducing cows are measured at every test day. This might explain the lack of a significant interaction term between the effect of SCC and mastitis treatment in the model.

\section{Effect of SCC and Mastitis Treatment in Previous Lactation}

Higher SCC in the previous lactation resulted in higher predicted production in the following lactation, all other things being equal. This can be seen as an estimate of the amount of milk that is necessary to make the farmer keep the cow despite an elevated SCC. When the variables for SCC and mastitis treatment in the lactation of interest was removed from the model, the estimate for the SCC of the previous lactation was negative, which has been shown in other studies (Fetrow et al., 1991; Houben et al., 1993). The positive relation between mastitis treatment in the previous lactation and production is larger than the findings in other studies, where no significant carryover effect was seen, except for cows with more than two treatments that had lower production in the following lactation (Lucey and Rowlands, 1984; Houben et al., 1993). The result in our study might be a result of the culling strategy of the farmers, where cows with chronic or severe inflammatory manifestations in the udder after mastitis treatment are culled.

\section{Effect on Herd Level}

The variance of the effect of mastitis treatment and SCC between animals was much larger than between herds, and no random effects related to SCC or mastitis treatment were significant on herd level when random effects on lactation level were included in the model. In relation to the SCC, this probably reflects a general effect of the SCC independent of herd effects though different udder pathogens affect the SCC to different extent (Haas et al., 2002). In relation to the effect of mastitis treatment, the absence of a herd effect is more surprising. The farmer's treatment decisions are complex and include many decisions of both tactical and emotional character leading to preferential treatment, resulting in some cows being treated for mild infections and other cows not being treated despite severe changes 
in the udder leading to drying of single quarters (Vaarst et al., 2002). Graphical exploration of the predicted losses at cow level showed that the losses varied considerably from year to year in the individual herds, and thus explains lack of consistent differences between farms. This might reflect changes in the character of mastitis in the herds or changing treatment policy caused by, e.g., quota restriction, and emphasizes the need for a continuous evaluation of the treatment policy in the herds.

\section{CONCLUSIONS}

The results of this study indicate that the milk losses related to SCC and mastitis treatment in Danish organic herds were comparable to the findings in conventional herds in other countries. The inclusion of effects for both SCC and mastitis treatment in the model allowed for differentiating the effect of treatment in relation to the SCC before treatment. The multilevel modeling approach gave a very robust estimation that did not change despite exclusion of major parts of the dataset. The approach also showed that the main variation in the data was between cows, and that grouping of herds according to production level, SCC or prevalence of mastitis treatment did not cause significant changes in the estimates related to SCC and mastitis. However, further development of the model to allow for estimation of production losses at the beginning of the first lactation is required. Estimation of the lactation curves and production losses from SCC and mastitis treatment at cow level is feasible and might be a useful tool for evaluating the effect of various disease treatments and culling decisions in dairy herds.

\section{REFERENCES}

Ali, A. K. A., and G. E. Shook. 1980. An optimum transformation for somatic cell concentration in milk. J. Dairy Sci. 63:487-490.

Bennedsgaard, T. W., S. M. Thamsborg, M. Vaarst, and C. Enevoldsen. 2003. Eleven years of organic milk production in Denmarkherd health and production related to time of conversion and compared to conventional production. Livest. Prod. Sci. 80:121-131.

Deluyker, H. A., J. M. Gay, and L. D. Weaver. 1993. Interrelationships of somatic cell count, mastitis, and milk yield in a low somatic cell count herd. J. Dairy Sci. 76:3445-3452.

Dentine, M. R., and B. T. McDaniel. 1983. Evidence for non-linearity in the relationship between milk and fat yields and the logarithm of the geometric mean of monthly somatic cell counts. J. Dairy Sci. 66 (Suppl. 1):112. (Abstr.)

Enevoldsen, C., K. B. Elgaard, N. P. Jensen, K. H. Nielsen, H. K. Nørregaard, and J. S. Philipsen. 2000. Identification of interactions and non-linear effects, assessment of herd effects, and model validation in a dairy herd health management context. Pages 1133-1134 in Proc. Ninth Symp. Int. Soc. Vet. Epidemiol. Econ. (ISVEE). M. D. Salman, P. S. Morley, and R. Ruch-Gallie, eds. Breckenridge, CO.
Fetrow, J., D. Mann, K. Butcher, and B. McDaniel. 1991. Production losses from mastitis: Carryover from the previous lactation. J. Dairy Sci. 74:833-839.

Gengler, N. 1996. Persistency of lactation yields: A review. Interbull Bull. 12:87-96.

Goldstein, H., 1995. Multilevel Statistical Models. 2nd ed. Arnold, London, UK.

Haas, Y. de, H. W. Barkema, and R. F. Veerkamp. 2002. The effect of pathogen-specific clinical mastitis on the lactation curve for somatic cell count. J. Dairy Sci. 85:1314-1323.

Hardeng, F., and V. L. Edge. 2001. Mastitis, ketosis, and milk fever in 31 organic and 93 conventional Norwegian dairy herds. J. Dairy Sci. 84:2673-2679.

Heringstad, B., G. Klemetsdal, and J. Ruane. 2001. Variance components of clinical mastitis in dairy cattle: Effects of trait definition and culling. Livest. Prod. Sci. 67:265-272.

Hortet, P., F. Beaudeau, H. Seegers, and C. Fourichon. 1999. Reduction in milk yield associated with somatic cell counts up to 600,000 cells $/ \mathrm{ml}$ in French Holstein cows without clinical mastitis. Livest. Prod. Sci. 61:33-42.

Hortet, P., and H. Seegers. 1998a. Calculated milk production losses associated with elevated somatic cell counts in dairy cows: Review and critical discussion. Vet. Res. 29:497-510.

Hortet, P., and H. Seegers. 1998b. Loss in milk yield and related composition changes resulting from clinical mastitis in dairy cows. Prev. Vet. Med. 37:1-20.

Houben, E. H. P., A. A. Dijkhuizen, J. A. M. van Arendonk, R. B. M. Huirne, and J. A. M. van Arendonk. 1993. Short- and long-term production losses and repeatability of clinical mastitis in dairy cattle. J. Dairy Sci. 76:2561-2578.

Jones, G. M., R. E. Pearson, G. A. Clabaugh, and C. W. Heald. 1984. Relationships between somatic cell counts and milk production. J. Dairy Sci. 67:1823-1831.

Koldeweij, E., U. Emanuelson, and L. Janson. 1999. Relation of milk production loss to milk somatic cell count. Acta Vet. Scand. $40: 47-56$.

Kreft, I. G. G., J. Leeuw, and L. S. Aiken. 1995. The effect of different forms of centering in hierarchical linear models. Multivar. Behav. Res. 30:1-21.

Kristensen, T., and E. S. Kristensen. 1998. Analysis and simulation modelling of the production in Danish organic and conventional dairy herds. Livest. Prod. Sci. 54:55-65.

Lucey, S., and G. J. Rowlands. 1984. The association between clinical mastitis and milk yield in dairy cows. Anim. Prod. 39:165-175.

Østergaard, S., and Y. T. Gröhn. 1999. Effects of diseases on test day milk yield and body weight of dairy cows from Danish research herds. J. Dairy Sci. 82:1188-1201.

Rajala-Schultz, P. J., Y. T. Gröhn, C. E. Mcculloch, and C. L. Guard. 1999. Effects of clinical mastitis on milk yield in dairy cows. J. Dairy Sci. 82:1213-1220.

Rasbash, J., W. Browne, H. Goldstein, M. Yang, I. Plewis, M. Healy, G. Woodhouse, D. Draper, I. Langford, and T. Lewis. 2001. A User's Guide to MLwiN. Version 2.1b. Institute for Education, London.

Singer, J. D. 1998. Using SAS PROC MIXED to fit multilevel models, hierarchical models, and individual growth models. J. Ed. Behav. Stat. 24:323-355.

Sjaunja, L. O., L. Baevre, L. Junkkarinen, J. Pedersen, and J. Setälä. 1990. A Nordic Proposal for an Energy Corrected Milk (ECM) Formula. Pages 156-157 in Performance recording of animals: State of the art 1990. EAAP Publication No. 50, Centre for Agricultural Publishing and Documentation, Wageningen, Netherlands.

Simianer, H., H. Solbu, and L. R. Schaeffer. 1991. Estimated genetic correlations between disease and yield traits in dairy cattle. J. Dairy Sci. 74:4358-4365.

Vaarst, M., C. Enevoldsen, and P. Jakobsen. 1993. Reports on diseases in 14 organic farms in Denmark. Acta Vet. Scand. Suppl. $0: 143-145$.

Vaarst, M., B. Paarup-Laursen, H. Houe, C. Fossing, and H. J. Andersen. 2002. Farmers' choice of medical treatment of mastitis in Danish dairy herds based on qualitative research interviews. J. Dairy Sci. 85:992-1001. 